University for Business and Technology in Kosovo

UBT Knowledge Center

UBT International Conference

2014 UBT International Conference

Nov 7th, 3:45 PM - 4:00 PM

\title{
Economics of milk yield losses in one dairy farm in Macedonia associated with clinical mastitis
}

\author{
Fetai Valdrina \\ FON University, valdrina_fetai@hotmail.com \\ Nakov Dimitar \\ Ss. Cyril and Methodius University \\ Jashari Besirm \\ Ministry of agriculture, forestry and water economy, Macedonia, besir.jasari@mzsv.gov.mk \\ Trajchev Metodija \\ Ss. Cyril and Methodius University, trajcevm@yahoo.com
}

Follow this and additional works at: https://knowledgecenter.ubt-uni.net/conference

Part of the Business Commons

\section{Recommended Citation \\ Valdrina, Fetai; Dimitar, Nakov; Besirm, Jashari; and Metodija, Trajchev, "Economics of milk yield losses in one dairy farm in Macedonia associated with clinical mastitis" (2014). UBT International Conference. 38. https://knowledgecenter.ubt-uni.net/conference/2014/all-events/38}

This Event is brought to you for free and open access by the Publication and Journals at UBT Knowledge Center. It has been accepted for inclusion in UBT International Conference by an authorized administrator of UBT Knowledge Center. For more information, please contact knowledge.center@ubt-uni.net. 


\title{
Economics of milk yield losses in one dairy farm in Macedonia associated with clinical mastitis
}

\author{
${ }^{1}$ Fetai Valdrina, ${ }^{2}$ Nakov Dimitar, ${ }^{3}$ Jashari Besirm, ${ }^{4}$ Trajchev Metodija \\ ${ }^{1}$ FON University, Faculty of Economy \\ ${ }^{2,4}$ University „St. Cyril and Methodius“, Faculty of Agricultural Sciences and Food, Institute for \\ Animal Biotechnology \\ ${ }^{3}$ Ministry of agriculture, forestry and water economy, State secretary, \\ ${ }^{1234}$ Skopje, Republic of Macedonia \\ 11 valdrina_fetai@ hotmail.com, ${ }^{3}$ besir.jasari@mzsv.gov.mk, ${ }^{4}$ trajcevm@yahoo.com
}

\begin{abstract}
Mastitis remains one of the major disease in dairy herds, causing profound economic losses to the entire milk production chain due to changes in the milk quality and milk yield. A one year crosssectional longitudinal survey was carried out to evaluate milk yield losses associated with occurrence of clinical mastitis cases in one dairy herd. Cows that had clinical mastitis and clinically healthy cows during lactation were included in the study. The traits analyzed were the average of the monthly test day milk yields, cow parities and days in lactation while first case of clinical mastitis was occurred. For these purpose there were recorded data for monthly test day milk yield of the cows at the $2^{\text {nd }}$, the $3^{\text {rd }}$ and the $4^{\text {th }}$ monthly test day (TD). TDs were chosen according to the average number of days in lactation to diagnose the first case of clinical mastitis. According these criteria, the $2^{\text {nd }}$ and the $3^{\text {rd }} \mathrm{TD}$ were made before the diagnosis of the first lactation case of clinical mastitis, while the $4^{\text {th }} \mathrm{TD}$ was made after the diagnosis. Monthly test day milk yields were treated as repeated measurement within an animal in General Linear Model (GLM). Statistical model included fixed effect of cow parity and covariance of days in lactation when the first case of clinical mastitis was occurred. Estimated lactation incidence risk (LIR) for CM in observed population of dairy cows was $21.49 \%$. Regardless parities, the first case of clinical mastitis in dairy herd occurred on the average 108.09 \pm 83.182 days in lactation. The LIR tended to significantly increased $(\mathrm{p}<0.001)$ with increasing the cow parity, as risk factor for occurrence of clinical mastitis. Before contracting the disease, cows with clinical mastitis yielded more milk than did healthy cows. Mastitis clearly affected the milk yield and the difference between the milk yield of the healthy cows and the cows after clinical mastitis was statistically significant. There was a significant decrease in the milk yield before and after the diagnosis of clinical mastitis case $(p<0.001)$. The estimated daily milk yield losses per cow suffered from case of clinical mastitis, between the $3^{\text {rd }}$ TD and the 4th TD, range from $0.9 \mathrm{~kg}$ to $26.0 \mathrm{~kg}$, or average $9.6 \mathrm{~kg} / \mathrm{day}$. According this, the monthly milk yield losses per mastitic cow, between the $3^{\text {rd }} \mathrm{TD}$ and the 4 th $\mathrm{TD}$, were $288 \mathrm{~kg}$. If we take in consideration the price of one $\mathrm{kg}$ milk of 0.32 euro, than the total daily economic losses per mastitic cow will be around 3 euro's and monthly losses per cow will be around 92 euro. Regardless of the time of occurrence during the lactation, mastitis had a long-lasting effect on milk yield; cows with clinical mastitis did not reach their premastitis milk yields during the remainder of the lactation after onset of the disease. The daily milk yield must be taken in consideration for more rapid economic analysis of milk losses associated with occurrence of clinical mastitis in dairy herds.
\end{abstract}

Keywords: dairy cows, economics, clinical mastitis, milk yield.

\section{Introduction}

Mastitis remains one of the major disease in dairy herds, causing profound economic losses to the entire milk production chain. Records for the occurrence of clinical mastitis (CM) in dairy cows have great importance for monitoring the health status of mammary gland and implementation of programs for control and eradication of this disease. Economic margins of dairy herds are, however, narrow. Optimization of the economic results, therefore, becomes important, and the need for cost minimization at every level of production is accentuated. A means of reducing the costs of production is to decrease the incidence of production disorders, as such are associated with reduced production, veterinary costs, and increased replacement rate, and, consequently, give rise to economically less efficient herds. 
Mastitis is of considerable interest because of its high incidence and the extensive costs associated with the disease.

Clinical mastitis incidence of dairy herds, reported in the literature, varied between 19 and 92 cases per 100 lactations (Sargeant et al. 1998, Shpigel et al. 1998). National data from countries which are the biggest milk producers, informed that annually 20 to $40 \%$ of dairy cows have expressed CM during lactation (Bartlett et al. 2001).

Indeed, mastitis is the most costly disease in dairy production (Degraves and Fetrow, 1993; Kossaibati and Esslemont, 1997; Seegers et al., 2003). Mastitis commonly occurs in cows with high milk production and has a long lasting effect on milk yield. The disease has a big influence on productivity and utilization of genetic potential of dairy cows. The effect of CM on milk yield can differ, depending on the parity and stage of lactation at which the disease occurs (Rajala and Grohn, 1998; Bennedsgaard et al. 2003; Grohn et al. 2006). The biggest milk yield losses were observed when CM was occurred in early lactation (Hagnestam et al. 2007). Clinical mastitis is associated with yield loss at the time of diagnosis, and, more importantly, yield loss often persists throughout lactation (Houben et al., 1993; Wilson et al., 2004). Actually, losses due to decreased milk production and milk quality had the biggest economic influence in dairy industry (Schukken et al. 1997).

There are numerous studies which reported the effects of CM on milk production. Some reviews about the relationship between $\mathrm{CM}$ and milk yield reported variability ranged from $3 \%$ to $8.1 \%$ for decrease in the milk yield per lactation and estimates of milk yield loss ranged from 160 to $850 \mathrm{~kg} / \mathrm{cow}$ per lactation (Bartlett et al. 1991, Grohn et al. 2004, Rajala et al. 1999, Smith et al. 2000). In a review by Hortet and Seegers (1998), the estimated lactational milk loss was found to vary between 0 and $9.5 \%$ across parities. Additional costs regarding mastitis are related with veterinary and treatment costs, the cost of discarded milk, extra labor requirement and increased risk of cow culling as well as mortality (Petrovski et al., 2006).

There are several analytical approaches that can be applied in the assessment of economic effects of disease and disease control. Which one that is most suitable for a certain analysis depends on the nature of the decision problem; the complexity of the disease and its effects; the data available; the intended use of the model and the preferences and capabilities of the model builder and/or decision maker; and the resources available (Bennett, 1992).

The aim of the current study was at assessing the economic losses associated with CM incidence in a dairy herd under current Macedonian farming condition, due to milk yield losses using monthly test day milk yields.

\section{Materials and methods}

This study was carried out in a dairy farm in the south-eastern region in R. Macedonia. The cows from black-white breed were housed in loose-housing system with enclosed shed. Milking is performed two times daily in milking parlor. The farm has a capacity of 1100 cows, from which at every moment 550 milking cows. Cows in the selected farm represented approximately $0.7 \%$ of high milk-yielding dairy cow population breeding in Republic of Macedonia.

The data were from 432 lactations with totally 1124 test day (TD) milk controls (360 TD milk yields collected in the second monthly milk control, 391 TD milk yields collected in the third monthly milk control and 373 TD milk yields collected in the fourth monthly milk control).

The incidence of new cases of CM was recorded daily, during the whole period, according to ordinary clinical methods under normal field conditions. Cows with CM were detected by clinical examination of the udder (rubber, tumor, color, dolor and function laesa) and determination of abnormalities in milk (presence of watery milk, flakes, clots, blood, pus, discolored milk, etc.) and disorders of general health condition of the animal (IDF 1987). Disease occurrence was expressed as lactation incidence risk (LIR).

$$
\operatorname{LIR}(\%)=\frac{\text { total number of clinical mastitis cases }}{\text { total number of observed lactation }} \times 100
$$

The traits analyzed were the average of the monthly test day milk yields. Parity of cows (P), disease dates, and yields from monthly test day milk sampling were available. Parity had five levels: 1, 2, 3, 4 
and 5 and higher. The first mastitis records during lactation were taken into consideration. The later cases of CM were ignored. Cases that occurred before calving or in a dry period were also excluded from the analyses. The selection of milk-controls was done according to the average number of days in lactation to diagnose the first case of $\mathrm{CM}$. These mean that the second and the third TD were done before the diagnosis of the first lactational case of CM, while the fourth TD was made after the diagnosis of the first lactational case of CM. Monthly test day milk yields, taken at approximately 30 days intervals, were used to study the relationship between CM and milk yield. To compare the milk yields associated with occurrence of $\mathrm{CM}$ in different lactation, estimates of the monthly test day milk yields for cows diagnosed with $\mathrm{CM}$ were calculated and compared with the yields of non-mastitic cows.

Statistical procedures were conducted in SPSS 20.0. The correlations between variables in the model ware calculated with Pearson's coefficient of correlation. Data analysis was carried out with GLMGeneral Linear Model with monthly test day milk yields as repeated measurement within an animal. Dependent variable in these analyses was binary value of CM which made difference between cows with case of CM during lactation and healthy cows. Statistical significance was evaluated on level $\mathrm{p}<0.05 ; \mathrm{p}<0.01$ and $\mathrm{p}<0.001$.

\section{Results}

The annual occurrence of CM in dairy farm that was include in research, calculated lactation incidence risk (LIR) are shown in Table 1.

Table 1 Annual prevalence rate and lactation incidence risk of CM by parity

\begin{tabular}{lllllll}
\hline & \multicolumn{6}{l}{ Number of consecutive lactation or cow parity } \\
& $\mathbf{1}$ & $\mathbf{2}$ & $\mathbf{3}$ & $\mathbf{4}$ & $\mathbf{5} \geq$ & Total \\
$\mathbf{L I R}^{\mathbf{b}}$ & $13.36 \%$ & $26.53 \%$ & $19.23 \%$ & $31.96 \%$ & $34.96 \%$ & $\mathbf{2 1 . 4 9 \%}$ \\
\hline
\end{tabular}

athe fifth and high lactation

${ }^{b}$ lactation incidence risk

According to the results, lactation incidence risk, for period of one year, was $21.49 \%$. The LIR increased with increasing the parity, or consecutive lactation, beginning from cows in the first lactation (13.36\%) up to cows in the fifth and higher lactation (34.96\%), but without linearity.

Figure 1 shows average days in lactation, separately for cows in different parity, while the first case of CM was diagnosed (DAY_CM).

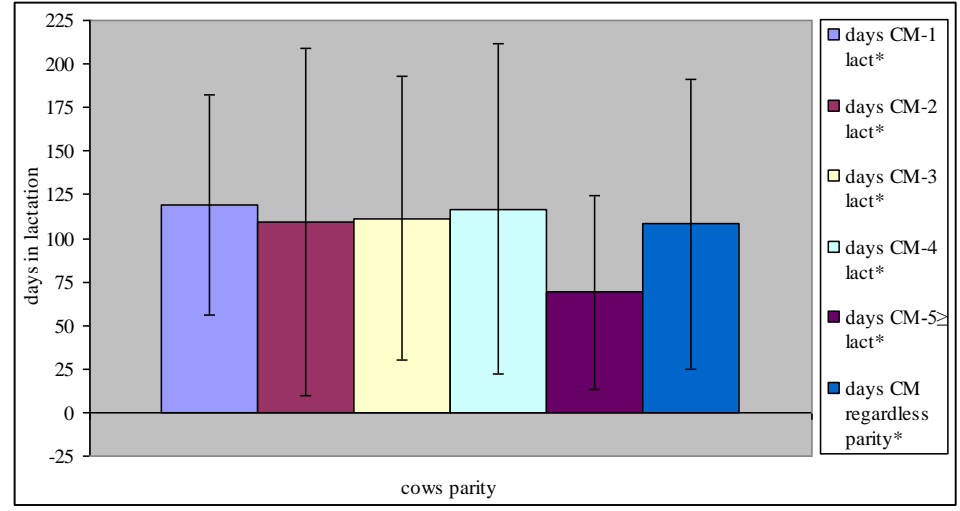

Figure 1 Average days in lactation \pm standard deviation until the first lactational case of $\mathrm{CM}$ occurred 
*average days in lactation \pm standard deviation until the first case of clinical mastitis was diagnosed, for cows in different parity and total for entire population of cows

Fom analysis of showed results in Figure 1 can be seen that there were some differences in the average number of days during lactation until the first case of CM was diagnosed (DAY_CM). Regardless parity of cows or number of consecutive lactation, the first case of CM in dairy herd has been occurred after average $108.09 \pm 83.182$ days in lactation.

In Table 2 are shown the average test day milk yields, separately for cows that suffer from case of CM and control group of healthy cows, in respect of number of consecutive lactation or cow parity.

Table 2 Average milk yields and standard deviation in the $2^{\text {nd }}$, the $3^{\text {rd }}$ and the $4^{\text {th }}$ monthly test day with respect to cows that suffer from case of $\mathrm{CM}$ and healthy cows

\begin{tabular}{|c|c|c|c|c|c|c|c|}
\hline \multicolumn{2}{|c|}{ Control of milk yield } & \multicolumn{2}{|l|}{ TDM2a } & \multicolumn{2}{|l|}{ TDM3 $^{\text {b }}$} & \multicolumn{2}{|l|}{ TDM4 $^{\mathrm{c}}$} \\
\hline Lactation & & $\begin{array}{l}\text { number } \\
\text { of milk } \\
\text { samples }\end{array}$ & $\begin{array}{l}\text { average } \\
\text { TD milk } \\
\text { yields }\end{array}$ & $\begin{array}{l}\text { number } \\
\text { of milk } \\
\text { samples }\end{array}$ & $\begin{array}{l}\text { average } \\
\text { TD milk } \\
\text { yields }\end{array}$ & $\begin{array}{l}\text { number } \\
\text { of milk } \\
\text { samples }\end{array}$ & $\begin{array}{l}\text { average } \\
\text { TD milk } \\
\text { yields }\end{array}$ \\
\hline \multirow{3}{*}{1} & $\begin{array}{l}\text { Cows with } \\
\text { case of } \mathrm{CM}\end{array}$ & 27 & $\begin{array}{l}22.541 \pm \\
6.6768\end{array}$ & 28 & $\begin{array}{l}22.443 \pm \\
5.7076\end{array}$ & 28 & $\begin{array}{l}14.121 \pm \\
5.2186\end{array}$ \\
\hline & $\begin{array}{l}\text { Healthy } \\
\text { cows }\end{array}$ & 113 & $\begin{array}{l}21.112 \pm \\
7.0794\end{array}$ & 128 & $\begin{array}{l}19.873 \pm \\
6.0473\end{array}$ & 121 & $\begin{array}{l}18.426 \pm \\
5.9403\end{array}$ \\
\hline & Total & 140 & $\begin{array}{l}21.388 \pm \\
7.0033\end{array}$ & 156 & $\begin{array}{l}20.335 \pm \\
6.0512\end{array}$ & 149 & $\begin{array}{l}17.617 \pm \\
6.0354\end{array}$ \\
\hline \multirow{3}{*}{2} & $\begin{array}{l}\text { Cows with } \\
\text { case of CM }\end{array}$ & 29 & $\begin{array}{l}29.924 \pm \\
11.3650\end{array}$ & 32 & $\begin{array}{l}24.294 \pm \\
10.9139\end{array}$ & 34 & $\begin{array}{l}13.565 \pm \\
7.8572\end{array}$ \\
\hline & $\begin{array}{l}\text { Healthy } \\
\text { cows }\end{array}$ & 57 & $\begin{array}{l}26.646 \pm \\
8.1518\end{array}$ & 56 & $\begin{array}{l}21.988 \pm \\
7.7746\end{array}$ & 43 & $\begin{array}{l}19.440 \pm \\
8.1329\end{array}$ \\
\hline & Total & 86 & $\begin{array}{l}26.740 \pm \\
9.2922\end{array}$ & 88 & $\begin{array}{l}22.826 \pm \\
9.0498\end{array}$ & 77 & $\begin{array}{l}16.845 \pm \\
8.4842\end{array}$ \\
\hline \multirow{3}{*}{3} & $\begin{array}{l}\text { Cows with } \\
\text { case of } \mathrm{CM}\end{array}$ & 11 & $\begin{array}{l}29.682 \pm \\
7.5670\end{array}$ & 13 & $\begin{array}{l}26.069 \pm \\
10.2119\end{array}$ & 14 & $\begin{array}{l}16.493 \pm \\
5.9922\end{array}$ \\
\hline & $\begin{array}{l}\text { Healthy } \\
\text { cows }\end{array}$ & 42 & $\begin{array}{l}25.064 \pm \\
8.6157\end{array}$ & 44 & $\begin{array}{l}18.511 \pm \\
7.8810\end{array}$ & 43 & $\begin{array}{l}17.891 \pm \\
8.0883\end{array}$ \\
\hline & Total & 53 & $\begin{array}{l}26.023 \pm \\
8.5507\end{array}$ & 57 & $\begin{array}{l}20.235 \pm \\
8.9596\end{array}$ & 57 & $\begin{array}{l}17.547 \\
7.6006\end{array} \pm$ \\
\hline \multirow{3}{*}{4} & $\begin{array}{l}\text { Cows with } \\
\text { case of CM }\end{array}$ & 18 & $\begin{array}{l}30.561 \pm \\
6.1404\end{array}$ & 21 & $\begin{array}{l}27.905 \pm \\
4.9144\end{array}$ & 25 & $\begin{array}{l}17.160 \pm \\
8.5784\end{array}$ \\
\hline & $\begin{array}{l}\text { Healthy } \\
\text { cows }\end{array}$ & 41 & $\begin{array}{l}23.593 \pm \\
9.3280\end{array}$ & 43 & $\begin{array}{l}22.370 \pm \\
9.8750\end{array}$ & 39 & $\begin{array}{l}18.864 \pm \\
9.1971\end{array}$ \\
\hline & Total & 59 & $\begin{array}{l}25.719 \pm \\
9.0295\end{array}$ & 64 & $\begin{array}{l}24.186 \pm \\
8.9184\end{array}$ & 64 & $\begin{array}{l}18.198 \pm \\
8.9306\end{array}$ \\
\hline
\end{tabular}




\begin{tabular}{|c|c|c|c|c|c|c|c|}
\hline \multirow{3}{*}{$5 \geq$} & $\begin{array}{l}\text { Cows with } \\
\text { case of } \mathrm{CM}\end{array}$ & 6 & $\begin{array}{l}25.517 \pm \\
6.9061\end{array}$ & 8 & $\begin{array}{l}28.287 \pm \\
11.2510\end{array}$ & 11 & $\begin{array}{l}11.882 \pm \\
6.4156\end{array}$ \\
\hline & $\begin{array}{l}\text { Healthy } \\
\text { cows }\end{array}$ & 16 & $\begin{array}{l}21.875 \pm \\
7.2623\end{array}$ & 18 & $\begin{array}{l}18.150 \pm \\
6.1091\end{array}$ & 15 & $\begin{array}{l}17.713 \pm \\
6.9549\end{array}$ \\
\hline & Total & 22 & $\begin{array}{l}22.868 \pm \\
7.1961\end{array}$ & 26 & $\begin{array}{l}21.269 \pm \\
9.1427\end{array}$ & 26 & $\begin{array}{l}15.246 \pm \\
7.2239\end{array}$ \\
\hline \multirow{3}{*}{ Total } & $\begin{array}{l}\text { Cows with } \\
\text { case of CM }\end{array}$ & 91 & $\begin{array}{l}26.584 \pm \\
8.8633\end{array}$ & 102 & $\begin{array}{l}25.069 \pm \\
8.7142\end{array}$ & 112 & $\begin{array}{l}14.707 \pm \\
7.1998\end{array}$ \\
\hline & $\begin{array}{l}\text { Healthy } \\
\text { cows }\end{array}$ & 269 & $\begin{array}{l}23.325 \pm \\
8.1492\end{array}$ & 289 & $\begin{array}{l}20.340 \pm \\
7.4432\end{array}$ & 261 & $\begin{array}{l}18.529 \pm \\
7.2644\end{array}$ \\
\hline & Total & 360 & $\begin{array}{l}24.149 \pm \\
8.4753\end{array}$ & 391 & $\begin{array}{l}21.573 \pm \\
8.0568\end{array}$ & 373 & $\begin{array}{l}17.382 \pm \\
7.4450\end{array}$ \\
\hline
\end{tabular}

a test day milk yields collected in the second monthly milk control, before the diagnosis of clinical mastitis

${ }^{\mathrm{b}}$ test day milk yields collected in the third monthly milk control, before the diagnosis of clinical mastitis

${ }^{c}$ test day milk yields collected in the fourth monthly milk control, after the diagnosis of clinical mastitis

The results from analysis in Table 2, which compared the milk yield of cows with CM with that of healthy cows, clearly indicated that before contracting the disease, cows with CM yielded more milk than did healthy cows. Milk yield began to decline in the third monthly milk control, before the diagnosis of $\mathrm{CM}$ in all parities and dropped below the yield of the healthy cows during the fourth monthly milk control, after the diagnosis of CM. CM gave rise to the most extensive yield loss in the $4^{\text {th }} \mathrm{TD}$ when the first lactation case was diagnosed. Multiparous cows generally suffered more severe yield loss than primiparous cows. The estimated daily milk yield losses per cow suffered from case of $\mathrm{CM}$, between the $3^{\text {rd }} \mathrm{TD}$ and the 4 th TD, range from $0.9 \mathrm{~kg}$ to $26.0 \mathrm{~kg}$, or average $9.6 \mathrm{~kg} / \mathrm{day}$. According this, the monthly milk yield losses per mastitic cow, between the $3^{\text {rd }} \mathrm{TD}$ and the 4 th TD, were $288 \mathrm{~kg}$. If we take in consideration the price of one $\mathrm{kg}$ milk of $€ 0.32$, than an average daily economic loss per mastitic cow within Macedonia quota system will be around $€ 3$ and average monthly losses per cow will be around $€ 92$. Here within are not calculated additional costs regarding mastitis in dairy farms.

Figure 2 represent relative differences in the monthly test day milk yields between cows with CM and healthy cows.

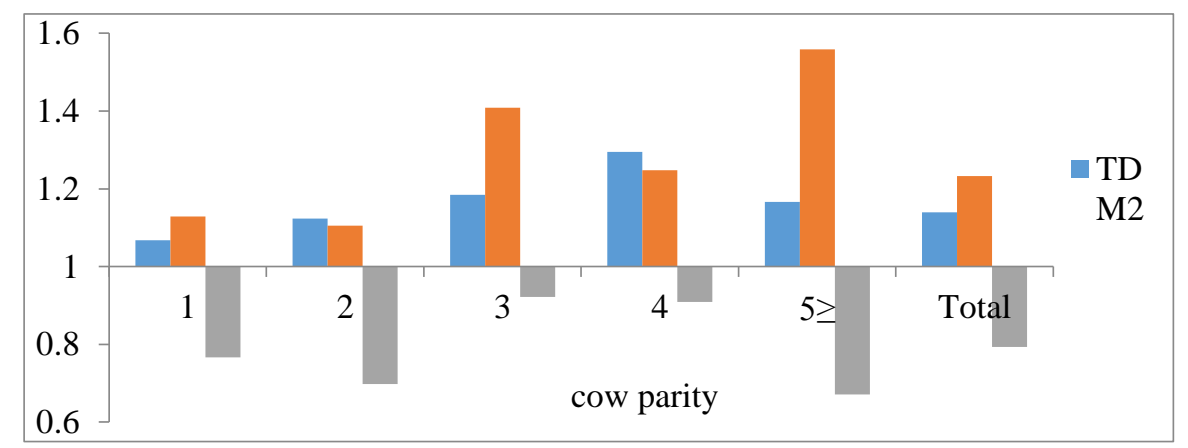

Figure 2 Proportional change in milk yield in cows diagnosed with CM in different TDM, expressed relative to milk yield of non-mastitic cows. 
Estimation of interdependence between variables in the statistical model was performed with Pearson's coefficient of correlation, showed in Table 3.

Table 3 Pearson's coefficient of correlation between study variables including in the statistical analysis

\begin{tabular}{llllll}
\hline Pearson's & P & DAY_CM & TDM2 & TDM3 & TDM4 \\
CM & $0.191^{\mathrm{b}}$ & $-0.764^{\mathrm{b}}$ & $-0.167^{\mathrm{b}}$ & $-0.258^{\mathrm{b}}$ & $0.236^{\mathrm{b}}$ \\
P & 1 & 0.079 & $0.149^{\mathrm{b}}$ & $0.104^{\mathrm{a}}$ & -0.024 \\
DAY_CM & & 1 & 0.089 & $0.140^{\mathrm{b}}$ & $-0.289^{\mathrm{b}}$ \\
TDM2 & & & 1 & $0.641^{\mathrm{b}}$ & $0.493^{\mathrm{b}}$ \\
TDM3 & & & & 1 & $0.488^{\mathrm{b}}$ \\
\hline
\end{tabular}

${ }^{a}$ significant at the $\mathrm{p}<0.05$ level

${ }^{\mathrm{b}}$ significant at the $\mathrm{p}<0.01$ level

In Table 4 is shown the statistical analysis of the factors considered in the model used for determination of influence on independent variables on incidence of CM between dairy cows.

Table 4 Results for influence of risk factors on incidence of $\mathrm{CM}$ according to the univariate procedure of GLM

\begin{tabular}{llll}
\hline $\begin{array}{l}\text { Dependent variable: incidence of CM } \\
\text { Source of variations }\end{array}$ & df & Mean square & F-value \\
Model & 9 & 114.593884 & $3146.280956^{\mathrm{a}}$ \\
P & 5 & 24.74110817 & $679.2899826^{\mathrm{a}}$ \\
DAY_CM & 1 & 34.86912584 & $957.3640646^{\mathrm{a}}$ \\
TDM2 & 1 & 0.089568658 & $2.459190268^{\mathrm{NS}}$ \\
TDM3 & 1 & 1.208834754 & $33.18967499^{\mathrm{a}}$ \\
TDM4 & 1 & 0.81403166 & $22.34999128^{\mathrm{a}}$ \\
e & 320 & 0.036422012 & \\
Total & 329 & & \\
$\mathbf{R}^{2}=\mathbf{0 . 9 8 9}$ & & & \\
\hline
\end{tabular}

${ }^{a}$ significant at the $\mathrm{p}<0.001$ level

${ }^{\mathrm{NS}}$ no significance

The effects of the cow parity and days in lactation when the case of CM during lactation was diagnosed on occurrence of $\mathrm{CM}$ were high significant $(\mathrm{p}<0.001)$. Mastitis clearly affected the milk yield and the difference between the milk yield of the healthy cows and the mastitic cows after CM was statistically significant. There was a significant decrease in the milk yield in the third monthly milk control, before the diagnosis of CM $(p<0.001)$, and during the fourth monthly milk control, after the diagnosis of CM $(\mathrm{p}<0.001)$. Value for $\mathrm{R}^{2}=0.989$ in the model was high, which means that variance for incidence of $\mathrm{CM}$ can be explained with source of variations. 


\section{Discussion}

Udder health is unfavourably genetically correlated with milk yield (Emanuelson et al., 1988; Heringstad et al., 2000; Carlen et al., 2004), and selecting only for increased production, which traditionally has been the focus of dairy cattle breeding in many countries, will therefore result in deterioration of udder health. The total economic cost of disease consists of two distinct components; production loss and control expenditures (McInerney et al., 1992). Losses include benefits that are taken away and benefits that are not realized. The former can be exemplified by milk that must be discarded following treatment with antibiotics and the latter by milk that is never produced as a result of disease. The high prevalence of CM in dairy herds makes considerable losses in milk production. The risk for occurrence of CM in these research was higher than the results of Bartlett et al. (1991) and Rajala and Grohn (1998), as $9.7-18.6 \%$, similar to the results of Sargeant et al. (1998) as 19,8\% and lower than the result of Firat (1993) as 35.8\%. The literature data are generally consistent about the reports that with increasing the parity of cow or the number of consecutive lactation, also increase the risk for occurrence a case of CM (Barkema et al. 1998, Sargeant et al. 1998, Shpigel et al. 1998). These increasing of LIR with increasing the cows parity in final statistical model showed significance $(\mathrm{p}<0.001)$ as risk factor for occurrence of CM. From analysis of showed results in Figure 1 can be seen that there were the differences between parities according the average number of days during lactation until the first case of CM was diagnosed. Our results were rather similar to results given from Shpigel et al. (1998). According them, 51.4\% from all cases of CM occurred within early and middle lactation, or approximately 117.5 days in lactation. These authors the increased risk for CM in early lactation explained by positive correlation between great milk production and mastitis. In addition, some researchers reported that mastitis risk might increase with the rise in the milk yield (Bartlett et al. 1991, Grohn et al. 1995, Smith et al. 2000).

The incidence of CM in primiparous and multiparous cows is more frequent in dairy herds with high milk production. These results are in accordance with some previous studies (Schutz 1994, Rajala and Grohn, 1998, Kocak 2006), which showed that increased milk yield was a risk for mastitis in dairy cows. Other studies have reported that increased milk yield could not be an indication for increased mastitis risk (Ouweltjes et al. 2007).

Several studies found that CM has a detrimental effect on milk yield (Bareille et al. 2003, Grohn et al. 2004, Shim et al. 2004). According Bar et al. (2007) milk yield began to drop after diagnosis of CM and the greatest loss occurred in the first week (up to $126 \mathrm{~kg}$.), and then gradually tapered to a constant value approximately two months after $\mathrm{CM}$. When there were compared the monthly test day milk production of cows with $\mathrm{CM}$ and healthy cows, according to the cow parity, it was seen that there were differences between the third and the fourth milk control, and these differences in statistical model showed significance at level $\mathrm{p}<0.001$. The amount of milk losses increased with increasing parity, with exception of the third and the fourth parity, and indicated that higher yielding older cows had greater losses. The most affected lactations according milk losses were the first, the second and the fifth or higher lactation. The lactation curves in all the other parities followed the same pattern. It is apparent from the figure that cows with CM usually have high milk yield than did their healthy counterparts despite disease. Before diagnosis, mastitic cows have a production advantage over their non-mastitic herd mates (estimated at $2.6 \mathrm{~kg}$ by Wilson et al. (2004)). As most studies use the yield level of nonmastitic cows as reference for yield in healthy cows, the reported losses probably underestimate the true yield loss associated with CM. According Nielsen (2009), the most extensive yield loss was estimated when CM developed in early lactation and when subclinical mastitis (SCM) occurred in late lactation. The 305-day yield loss associated with CM varied between 0 and $705 \mathrm{~kg}$ milk in primiparous cows and between 0 and $902 \mathrm{~kg}$ milk in multiparous cows, depending on lactation week at onset. Most cases of $\mathrm{CM}$ developed in the first week of lactation and resulted in a yield loss of 578 and $782 \mathrm{~kg}$ milk in primiparous and multiparous cows, respectively.

In the review, Hortet and Seegers (1998) summarised a lactational yield loss of 300 to $400 \mathrm{~kg}$ (4 to $6 \%$ ) in multiparous cows and 200 to $300 \mathrm{~kg}$ in primiparous cows. Cases of CM are of different severity, and $40 \%$ of CM cases can be expected to be associated with negligible yield loss, $30 \%$ with a lactational yield loss of $150 \pm 250 \mathrm{~kg}$, and $30 \%$ with a lactational yield loss of $950 \pm 1050 \mathrm{~kg}$. Although the economics of mastitis has been covered in scientific literature (Halasa et al., 2007). 
Also, the losses in the milk yield before the clinical diagnosis of mastitis in dairy cows have been previously reported (Bartlett et al. 1991, Grohn et al. 2004). These losses could be an indication of subclinical infection before the signs start or the early stages of CM could be undetectable to the herdsperson. Similarly to the current study, Rajala et al. (1999) reported a significant decrease in the milk yield of mastitic cows 28 days before the diagnosis of the case of CM. According them, daily losses in milk yields in the first two weeks after case of CM was diagnosing, vary between $1 \mathrm{~kg}$ and 2,5 $\mathrm{kg}$, independence from number of infected mammary gland quarters, and total lactation milk losses was ranged from $110 \mathrm{~kg}$ up to $325 \mathrm{~kg}$. These authors reported that the daily milk yield of mastitic cows, one week before the diagnosis, significantly decreased for parity $3(2.4 \mathrm{~kg} /$ day $)$ and parity $4(2.2 \mathrm{~kg} /$ day $)$ but not for parity 1 (1 kg/day) and $2(0.8 \mathrm{~kg} /$ day $)$. After mastitis, the cows were not able to reach their before-mastitis milk yield during the rest of the lactation. Kocak (2006) reported that there are statistically significant decreasing in milk yield one week before the diagnoses of CM and one week after the diagnoses. According Wu et al. (2008), association between milk production and occurrence of $\mathrm{CM}$ is very complex, and there is reversing proportionality between them. Their results showed that increased incidence of $\mathrm{CM}$ in dairy herds decreased the milk yield in next milk control. Therefore, culling the cows that are more prevalent to CM has double effect because at the same time we culling the cows with decreased milk production and make selection for mastitis resistance.

\section{Conclusions}

Clinical mastitis clearly affected the milk yield one month before and after diagnoses of disease. The results of this study are of practical interest to dairy farmers, showing that preventative measures should be focused on reducing the frequency of CM between calving and peak yield, especially during third and fourth months of lactation, because this is the period when the majority of cases occur and when yield losses are the most extensive. The primary purpose of economic analyses is to support decisions regarding mastitis control.

\section{References}

1) Bar, D., Grohn, Y.T., Bennett, G., Gonzalez, R.N., Hertl, J.A., Schulte, H.F., Tauer, L.W., Welcome, F.L. and Schukken, Y.H. 2007. Effect of Repeated Episodes of Generic Clinical Mastitis on Milk Yield in Dairy Cows. J Dairy Sci 90: 4643-4653.

2) Bareille, N., Beaudeau, F., Billon, S., Robert, A., Faverdin, P. 2003. Effects of health disorders on feed intake and milk production in dairy cows. Livest Prod Sci 83: 53-62.

3) Barkema, H.W., Schukken, Y.H., Lam, T.J.G.M., Beiboer, M.L., Wilmilk, H., Benedictus, G., Brand, A. 1998. Incidence of clinical mastitis in dairy herds grouped in three categories by bulk milk somatic cell counts. J Dairy Sci 81: 411-419.

4) Bartlett, P.C., Van Wijk, J., Wilson, D.J., Green, C.D., Miller, G.Y., Majewski, G.Y., Heider, L.E. 1991. Temporal patterns of lost milk production following clinical mastitis in large Michigan Holstein herd. J Dairy Sci 74: 1561-1572.

5) Bartlett, P.C., Agger, J.F., Houe, H., Lawson, L.G. 2001. Incidence of clinical mastitis in Danish dairy cattle and screening for non-reporting in a passively collected national surveillance system. Prev. Vet. Med. 48, 73-83.

6) Bennedsgaard T.W., Enevoldsen C., Thamsborg S.M., Vaarst, M. 2003. Effect of Mastitis Treatment and Somatic Cell counts on Milk Yield in Danish Organic Dairy Cows. J Dairy Sci 86, 3174-3183. 
7) Bennett, R., Christiansen, K. and Clifton-Hadley, R. 1999. Preliminary Estimates of the Direct Costs Associated with Endemic Diseases of Livestock in Great Britain. Prev Vet Med 39(3), 155-171.

8) Carlen, E., Strandberg, E. and Roth, A. 2004. Genetic Parameters for Clinical Mastitis, Somatic Cell Score, and Production in the First Three Lactations of Swedish Holstein Cows. J Dairy Sci 87(9), 3062-3070.

9) Degraves, F.J. and Fetrow, J. 1993. Economics of Mastitis and Mastitis Control. Veterinary Clinics of North America-Food Animal Practice 9(3), 421-434.

10) Emanuelson, U., Danell, B. and Philipsson, J. 1988. Genetic Parameters for Clinical Mastitis, Somatic Cell Counts, and Milk Production Estimated by Multiple-Trait Restricted-Maximum Likelihood. J Dairy Sci 71(2), 467-476.

11) Firat, M.Z. 1993. Susceptibility of clinical mastitis in successive lactations. Livestock prod. sci. 34(1-2), 175-180.

12) Grohn, Y.T., Eicker, S.W., Hertl, J.A. 1995. The association between previous 305-day milk yield and disease in New York state dairy cows. J. Dairy Sci. 78, 1693-1702.

13) Grohn, Y.T., Wilson, D.J., Gonzalez, R.N., Hertl, J.A., Schulte, H., Bennett, G., Schukken, Y.H. 2004. Effect of pathogen-specific clinical mastitis on milk yield in dairy cows. J Dairy Sci 87: 3358-3374.

14) Grohn, Y.T., Gonzalez, R.N., Hertl, J.A., and Schukken, Y.H. 2006. Cumulative effect of clinical mastitis episodes on dairy cow milk yield. In: Proceedings from the $11^{\text {th }}$ Symposium of the International Society for Veterinary Epidemiology and Economics, Cairns, Australia, 481.

15) Hagnestam, C., Emanuelson, U., and Berglund, B. 2007. Yield losses associated with clinical mastitis occurring in different weeks of lactation. J Dairy Sci 90, 2260-2270.

16) Halasa, T.H., Huijps, K., Osteras, O., Hogeveen, H., 2007. Economic effects of bovine mastitis and mastitis management: A review. Vet. Quarterly 29, 18-31.

17) Heringstad, B., Klemetsdal, G., and Ruane, J. (2000). Selection for mastitis resistance in dairy cattle: a review with focus on the situation in the Nordic countries. Livestock Production Science 64, pp. 95-106.

18) Hortet, P. and Seegers, H. 1998. Loss in milk yield and related composition changes resulting from clinical mastitis in dairy cows. Prev Vet Med 37: 1-20.

19) Houben, E.H.P., Dijkhuizen, A.A., Vanarendonk, J.A.M. and Huirne, R.B.M. 1993. ShortTerm and Long-Term Production Losses and Repeatability of Clinical Mastitis in Dairy Cattle. J Dairy Sci 76(9), 2561-2578.

20) International Dairy Federation. 1987. Bovine Mastitis. Definitions and guidelines for diagnosis. Bull. Int. Dairy Federation. 211, 3-8.

21) Lucey, S., Rowlands, G.J., Russell, A.M. 1986. Short-term associations between disease and milk yield of dairy cows. J Dairy Res 53: 7-15.

22) Kocak, O. 2006. Influence of Mastitis on Milk Yield in Holstein Cows. Acta Vet. Brno, 75, 507-513. 
23) Kossaibati, M.A. and Esslemont, R.J. 1997. The Costs of Production Diseases in Dairy Herds in England. Vet J 154(1), 41-51.

24) McInerney, J.P., Howe, K.S. and Schepers, J.A. 1992. A Framework for the Economic Analysis of Disease in Farm Livestock. Prev Vet Med 13(2), 137-154.

25) Nielsen, C. 2009. Economic impact of mastitis in dairy cows. Doctoral thesis, Swedish University of Agricultural Sciences, Uppsala.

26) Ostergaard, S. and Grohn, Y.T. 1999. Effects of diseases on test day milk yield and body weight of dairy cows from Danish research herds. J. Dairy Sci. 82:1188-1201.

27) Ouweltjes, W., Beerda, B., Windig, J.J., Calus, M.P.L. and Veerkamp, R.F. 2007. Effects of management and genetics on udder health and milk composition in dairy cows. J. Dairy Sci. $90,229-238$.

28) Petrovski, K.R., Trajcev, M., and Buneski, G. (2006). A review of the factor affecting the cost of bovine mastitis.Tydskr.S.Afr.Ver.77(2), pp. 52-60.

29) Rajala, P.J. and Grohn, Y.T. 1998. Disease occurrence and risk factor analysis in Finnish Ayrshire cows. Acta Veterinaria Scandinavica.39: 1, 1-13.

30) Rajala-Schultz, P.J., Grohan, J.T., McCulloch, C.E., and Guard, C.L. 1999. Effects of Clinical Mastitis on Milk Yield in Dairy Cows. J Dairy Sci 82, 1213-1220.

31) Sargeant, J. M., Scott, M., Leslie, M., Ireland, K.E., Bashiri, M. J. A. 1998. Clinical mastitis in dairy cattle in Ontario: frequency of occurrence and bacteriological isolates. Can. Vet. J. 39, 33-38.

32) Schukken, Y.H., Lam, T. J. G. M. and Barkema, H. W. 1997. Biological basis for selection on udder health traits. In: Proc. International workshop on genetic improvement of functional traits in cattle; health. Uppsala, Sweden, June 1997, Interbull Bulletin 15, 27-33.

33) Schutz, M.M., VanRaden, P.M., and Wiggans, G.R. 1994. Genetic variation in lactation means of somatic cell scores for six breeds of dairy cattle.J. Dairy Sci. 77:284.

34) Shim, H.E., Shanks, R.D., Morin, D.E. 2004. Milk loss and treatment costs associated with two treatment protocols for clinical mastitis in dairy cows. J Dairy Sci 87: 2702-2708.

35) Shpigel, N.Y., Winkler, M., Ziv, G., Saran, A. 1998. Clinical, bacteriological and epidemiological aspects of clinical mastitis in Israeli dairy herds Prev. Vet. Med. 35, 1-9.

36) Seegers, H., Fourichon, C. and Beaudeau, F. 2003. Production Effects Related to Mastitis and Mastitis Economics in Dairy Cattle Herds. Ve. Res 34(5), 475-491.

37) Smith, J.W., Ely, L.O., Chapa, A.M. 2000. Effect of region, herd size and milk production on reasons cows leave the herd. J. dairy sci. 83(12), 2980-2987.

38) Wilson, D.J., Gonzalez, R.N., Hertl, J.A., Schulte, H.F., Bennett, G.J., Schukken, Y.H. and Grohn, Y.T. 2004. Effect of Clinical Mastitis on the Lactation Curve: A Mixed Model Estimation Using Daily Milk Weights. J. Dairy Sci. 87(7), pp. 2073-2084. 